\title{
A LÍNGUA FRANCA DO IMPÉRIO: QUÉCHUA, UMA TRADIÇÃO QUE PERDURA
}

\section{José Paulo da Silva ${ }^{1}$ \\ Anézio Cláudio Bernardes ${ }^{2}$}

Resumo: Esta pesquisa tem por objetivo apresentar a resistência da língua veicular do império Inca frente à cultura dominante europeia, considerando que a língua Quéchua foi adotada como a língua oficial, usada como comunicação entre a elite administrativa Inca, na capital do Império, em Cusco, como forma de domínio aos povos anexados ao império, e, também, utilizada como língua geral na conquista espanhola. Os dados apontam que, mesmo com a colonização marcante europeia e a imposição e continuidade da língua castelhana, atualmente a língua Quéchua é considerada como a língua nativa mais falada na América Espanhola; ela sobreviveu e se preservou até os dias de hoje por meio da promulgação de leis de sua preservação. Ela é reconhecida em mídias impressas e televisivas, e no contexto educacional e político. Esse processo de preservação e conhecimento da língua dos seus ancestrais proporcionou uma integração dos povos de origem inca com suas raízes culturais.

Palavras-chave: Língua; Quéchua; Inca; Cultura; Identidade.

\footnotetext{
${ }^{1}$ História/Faculdade de Educação e Artes/Univap-Platanus, Brasil. E-mail: josepaulosp@globomail.com.

2 Letras/Faculdade de Educação e Artes/Univap-Urbanova, Brasil. E-mail: acb@univap.br.
} 